\title{
The concordance of optic nerve sheath diameter measurements with the clinical course in children with traumatic head injury
}

\author{
다 Rasime Pelin Kavak, M.D., ${ }^{1}$ (ㄷ Meltem Özdemir, M.D., ${ }^{1}$ ㄴ) Nezih Kavak, M.D., ${ }^{2}$ \\ 다 Nurcan Ertan, M.D., ${ }^{1}$ Bahadır Külah, M.D. ${ }^{3}$
}

\begin{abstract}
1'Department of Radiology, University of Health Sciences Dışkapı Yıldırım Beyazıt Training and Research Hospital, Ankara-Turkey ${ }^{2}$ Department of Emergency Medicine, University of Health Sciences Dışkapı Yıldırım Beyazıt Training and Research Hospital, Ankara-Turkey ${ }^{3}$ Department of General Surgery, A Life Park International Academic Hospital, Ankara-Turkey
\end{abstract}

\begin{abstract}
BACKGROUND: Intracranial pressure (ICP) monitoring is of profound importance concerning prognosis and treatment among children with traumatic brain injury (TBI). Measurements of the optic nerve sheath diameter (ONSD) are one of the methods recommended for ICP monitoring. In this study, we aimed to evaluate the correlation of ONSD change in brain computed tomography (CT) with pediatric Glasgow Coma Score (pGCS) in the follow-up of pediatric cases with TBI, and also to evaluate the usability of the ONSD, which is the indicator of ICP.
\end{abstract}

METHODS: The data of 921 pediatric patients who were admitted to the emergency department with head injury between January 2016 and January 2018 were retrospectively evaluated in this study. Age, gender, trauma type, brain CT finding, pGCS, type of intracranial hemorrhage (ICH), and isolated skull fracture (ISF) were investigated. The patients were evaluated in three groups based on CT findings: (i) patients with parenchymal brain injury, (ii) patients with ISF, and (iii) patients with normal brain CT results. The measurements of ONSD were performed using CT. Whether the ONSD measurement results of the patients were compatible with the clinical data was investigated.

RESULTS: The median age of the patients was 36 months (interquartile range $[\mathrm{IQR}]=64$ ) and $64.2 \%$ were male. The ONSD values and pGCSs of the patients with parenchymal injury were found to be significantly higher than patients with ISF and normal brain $C T$ findings $(p<0.05)$. The $p G C S s$ showed a significant negative correlation with the first and second measurement results of ONSD $(p<0.05)$. In groups undergoing control brain CT, ONSD levels in the second brain CT were found to be significantly high $(p<0.05)$.

CONCLUSION: In the clinical follow-up, ONSD measurements are reliable and significant parameters when evaluated with brain CT findings and pGCSs. We think that repeated ONSD measurements will be useful in determining possible adverse effects of secondary injury, as well as in determining the severity of the trauma during admission.

Keywords: Intracranial pressure; optic nerve sheath diameter; traumatic brain injury.

\section{INTRODUCTION}

Severe traumatic brain injury (TBI) is the leading cause of mortality and morbidity in children. ${ }^{[I]}$ Pathophysiologic characteristics and management options are different from those in adults. These differences result from age-related structural change, injury mechanisms related to the ability of the child and difficulty in neurologic evaluation of pediatric patients. ${ }^{[1-3]}$

There are two mechanisms that cause TBI. The first cause is primary injuries resulting from direct trauma, and the second cause is secondary injuries due to metabolic causes,

Cite this article as: Kavak RP, Özdemir M, Kavak N, Ertan N, Külah B. The concordance of optic nerve sheath diameter measurements with the clinical course in children with traumatic head injury. Ulus Travma Acil Cerrahi Derg 2020;26:728-734.

Address for correspondence: Rasime Pelin Kavak, M.D.

Sağlık Bilimleri Üniversitesi Dışkapı Yıldırım Beyazıt Eğitim ve Araştırma Hastanesi, Radyoloji Kliniği, Ankara, Turkey

Tel: +90 312 - 5962000 E-mail: drrpelindemir6@hotmail.com 
such as hypoxia, hypercapnia, hypotension, increased intracranial pressure (ICP) and hyperglycemia. ${ }^{[4]}$ Although it is not possible to avoid primary injuries, secondary injuries can be prevented by minimizing metabolic causes. The increase in brain edema may lead to increased ICP, resulting in mortality. Increased ICP may cause secondary injuries by decreasing cerebral perfusion and cerebral blood flow. If no intervention is made, this will continue in a vicious circle until the patient dies. Therefore, monitoring of ICP and identification of any elevation are of vital importance. ${ }^{[5-7]}$ The monitoring of ICP plays an important role in treatment in pediatric patients as in adults and predicts morbidity and mortality significantly. ${ }^{[8]}$ Monitoring of ICP is a method that can be measured invasively under normal conditions, has complications, and requires technical equipment. ${ }^{[9,10]}$

The measurement of optic nerve sheath diameter (ONSD) using different radiological imaging techniques has become a popular non-invasive method for monitoring ICP. There are studies reporting that computed tomography $(\mathrm{CT})$, magnetic resonance imaging and ultrasonography (USG) can also be used for this purpose. ${ }^{[1-14]}$ The ONSD diameter has been reported to increase if there is an increase in the ICP since the dura mater extends to surround the optic nerve, and the most suitable area for the measurement has been reported to be $3 \mathrm{~mm}$ behind the globe in particular. ${ }^{[7,9]}$

Pediatric Glasgow Coma Score (pGCS) is a significant scoring system that can be used in the follow-up of patients with TBI and can guide the clinician. According to the current data, ICP monitoring is important in the management of treatment in cases with a PGCS of 8 or less. ${ }^{[5,8,12]}$

We aimed to investigate the correlation between the ONSD change on brain CT used in the follow-up of pediatric patients with TBI and PGCS and the usability of ONSD, an indicator of ICP, in the follow-up of patients.

\section{MATERIALS AND METHODS}

After ethical committee approval, medical records of 921 pediatric patients admitted to the emergency department of our hospital with complaints of traumatic head injury between I January 2016 and I January 2018 were retrospectively reviewed in this study. Age, gender, trauma type, brain CT finding, pGCS, type of intracranial hemorrhage (ICH) and isolated skull fracture (ISF) were analyzed. The patients were divided into three groups according to the CT findings such as parenchymal brain injury, ISF and normal CT finding. The medical records of pediatric patients with intracranial mass, head trauma-induced ocular or orbital injury, previous optic nerve trauma, and brain surgery were excluded from this study. The presence of artifacts obscure the visualization of the optic nerve on CT imagining was accepted as exclusion criteria.

It was investigated whether there was a significant difference between the first brain $\mathrm{CT}$ and control brain $\mathrm{CT}$ concerning ONSD width among patients undergoing control CT due to additional symptoms or changes in the clinical condition.

\section{CT Protocol and Measurement of ONSD}

CT examinations were performed with a 64-detector row CT machine (GE Optima 660 SE 64 Detector I28-slice CT, General Electric Medical Systems, Milwaukee, WI). The standardized pediatric brain CT protocols were based on the following: effective dose level of $65-110 \mathrm{mAs}$, $110 \mathrm{kVp}, 20 \mathrm{~mm}$ collimation, $5 \mathrm{~mm}$ thickness reconstruction at $5 \mathrm{~mm}$ intervals, 0.5 second rotation time. The CT protocol using $0.625 \mathrm{~mm} * 32$ row contiguous slices. $20 \mathrm{~mm}(32 * 0.625)$ detector coverage was used for all brain non-contrast acquisition. In addition, radiation-sensitive organs, such as gonads are routinely protected from radiation with shields. Suitable dose sedative was used in uncooperative pediatric patients if required.

All ONSD measurements have been performed on the initial brain CT images obtained upon admission to the ED. Images demonstrated the maximum width of the optic nerve was chosen and the retrobulbar area was magnified five times. The ONSD was measured from one side of the optic nerve sheath to the other site $3 \mathrm{~mm}$ behind the posterior globe margin in a perpendicular vector in reference to the linear axis of the optic nerve (Fig. Ia-c). ONSD measurements were carried out using electronic calipers on the Extreme Picture Archiving and Communication System (ExtremePacs, Ankara, Turkey). The average of the right and left eye optic nerve sheath measurements was taken in millimeters $(\mathrm{mm})$ as the mean ONSD value for the final analysis. All the measurements were made on images through the brain window using the same window settings for all patients. Two experienced radiologists (R.P.K and M.Ö.) examined the brain CT images and made the repeated ONSD measurements in a blinded manner for the clinical data of the patients.

\section{Statistical Analysis}

Statistical analysis was performed using Statistical Package for the Social Sciences, Version 22.0 (SPSS Inc., Chicago, IL). Categorical data were analyzed by Chi-Square test. The distribu-

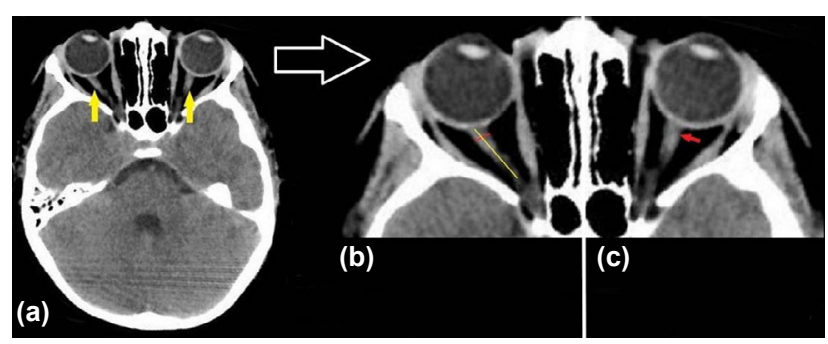

Figure 1. Axial computed tomography section demonstrating the optic nerves (yellow arrows) (a). ONSD was measured $3 \mathrm{~mm}$ behind the insertion of the optic nerve into the globe, on a perpendicular line (red line), with reference to the linear axis of the optic nerve (yellow line) (b). Note the location where the optic nerve sheath diameter measurement was performed (red arrow) (c). 

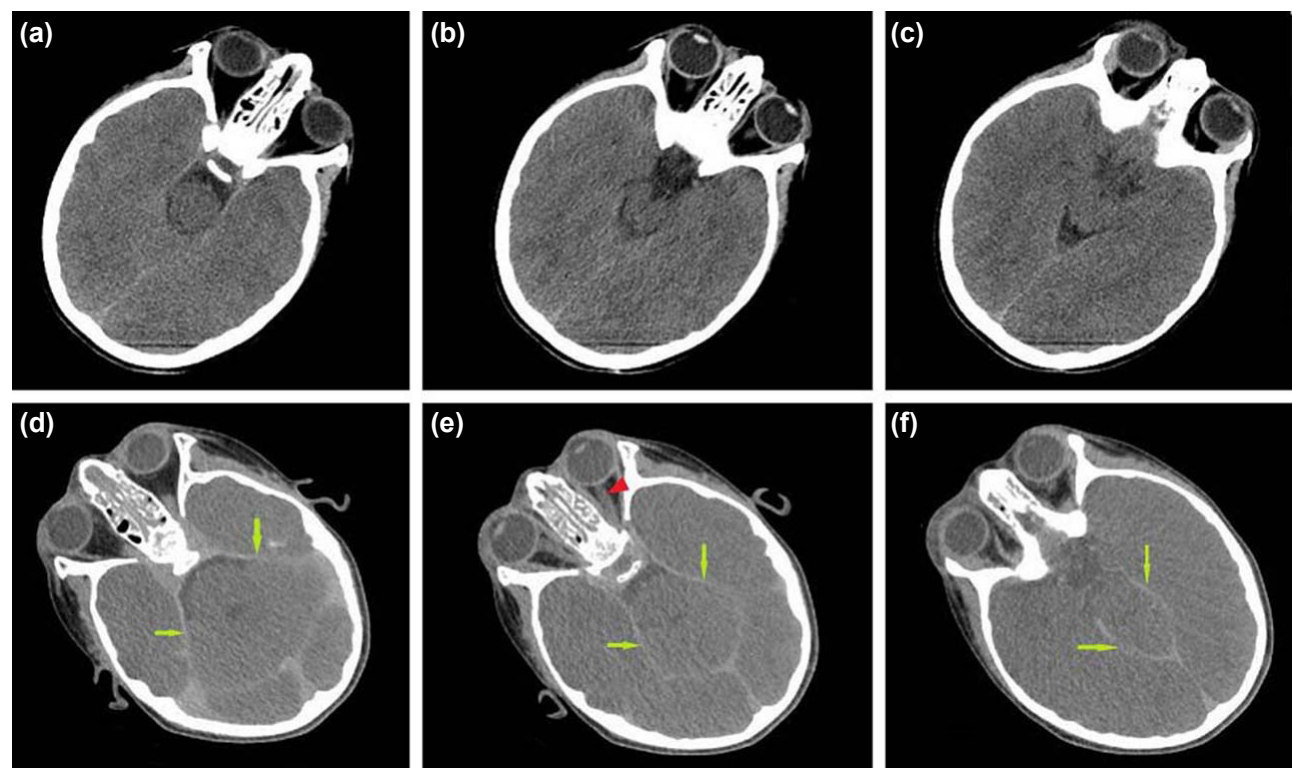

Figure 2. Axial computed tomography sections of a patient with isolated head trauma obtained at admission (a-d) and at $24^{\text {th }}$ hour following the trauma (d-f). Note the development of subarachnoid hemorrhage (green arrows in d-f) and the noticeable increase in the optic nerve sheath diameter in the sections obtained $24^{\text {th }}$ hour following the trauma (red arrowhead in e).

tion of the data was analyzed using the Kolmogorov-Smirnov test. Upon determining that quantitative data is non-parametric, a Mann-Whitney $U$ test or Kruskal Wallis test was used to analyze the data with categorical variables. Quantitative (parametric) variables were presented as median and interquartile range (IQR) deviation, and qualitative (nonparametric) variables were expressed as observed numbers and percentages. The change between the ONSD on brain CT taken at the time of admission and ONSD on control brain CT was measured using the Paired Samples t-test. These data were expressed as mean and standard deviation. Spearman's rank correlation analysis was used to compare ONSD values and PGCS. P-values less than 0.05 were considered statistically significant.

\section{RESULTS}

The median age of the patients was 36 months (IQR=64) and $64.2 \%$ were male. The median age of patients with parenchymal injury and ISF was found to be significantly higher than patients with normal brain CT findings $(p<0.05)$. The patients were most frequently admitted with fall and the frequency of parenchymal injury was significantly higher in these patients $(p<0.05)$. The most common parenchymal injury was subarachnoid hemorrhage.

The ONSD values of the patients with parenchymal injury were found to be significantly higher than those with ISF and normal CT findings $(p<0.05)$. No difference was observed between the patients with ISF and those with normal brain CT findings in terms of the ONSD measurements $(p>0.05)$. The PGCSs of the patients with parenchymal injury were found to be significantly lower than those with ISF and normal CT findings $(p<0.05)$. No difference was observed between the patients with ISF and patients with normal brain CT findings concerning pGCSs $(p>0.05)$. The mortality rate was $5.8 \%$ in the present study, and it was significantly higher in patients with parenchymal injury $(p<0.05)$ (Table I).

The pGCSs showed a significant negative correlation with the first and second measurement results of ONSD $(p<0.05)$ (Table 2).

Control brain CT was observed to be performed in 755 (82\%) of the cases. In groups undergoing control CT, ONSD levels in the second brain CT were found to be significantly high $(p<0.05)$ (Table 3) (Fig. 2a-f).

\section{DISCUSSION}

There are many studies in the literature showing that ONSD increases with the increased ICP in patients with TBI. ${ }^{[3,15]}$ Control brain CT can also be performed if there is a clinical worsening or change during follow-up of patients with TBI, or in the follow-up of patients. In the present study, ONSD values on the control brain $C T$ s have been examined and the relationship between impaired clinical status and ICP increase has been investigated. The relationship of the existing change with ICP increase has been evaluated and it has been investigated whether ONSD could be used in the prognosis of patients without additional examination. The ONSD has been observed to increase in control brain CTs in patients with impaired clinical status, regardless of the presence of parenchymal injury. A significant relationship has been found between this change and the PGCSs of the patients.

In studies involving pediatric patients, it has been reported 
Table I. Demographic and clinical characteristics of the groups

\begin{tabular}{|c|c|c|c|c|c|}
\hline & $\begin{array}{c}\text { The causes of } \\
\text { traumatic } \\
\text { head injury }\end{array}$ & $\begin{array}{c}\text { Brain parenchymal } \\
\text { damage } \\
\text { n (\%) }\end{array}$ & $\begin{array}{c}\text { Isolated skull } \\
\text { fracture } \\
\text { n (\%) }\end{array}$ & $\begin{array}{c}\text { Normal brain } \\
\text { CT findings } \\
\text { n (\%) }\end{array}$ & $\mathbf{p}$ \\
\hline Age (month), median (IQR) & & $48(74)$ & $24(52)$ & $12(12)$ & $<\left.0.00\right|^{a, b}$ \\
\hline Male/female (n) & & $350 / 121$ & $|13 / 8|$ & $128 / 128$ & $<0.001$ \\
\hline \multicolumn{6}{|l|}{ Trauma mechanism, $\mathrm{n}(\%)$} \\
\hline Fall & $26 I(55.4)$ & $132(68)$ & $120(46.9)$ & $<0.001$ & \\
\hline Motor vehicle accident & $178(37.8)$ & $62(32)$ & $136(53.1)$ & & \\
\hline Others (e.g., gunshot wounds) & $32(6.8)$ & - & - & & \\
\hline \multicolumn{6}{|l|}{ Type of parenchymal damage, n (\%) } \\
\hline Subarachnoid hemorrhage & $245(27)$ & & & & \\
\hline Subdural hemorrhage & $120(13)$ & & & & \\
\hline Epidural hemorrhage & $113(12)$ & & & & \\
\hline Cerebral contusion & $105(\mathrm{II})$ & & & & \\
\hline Cerebral edema & $74(8)$ & & & & \\
\hline I. ONSD (mm), median (IQR) & & $5.36(1)$ & $3.60(I)$ & $3.99(1)$ & $<\left.0.00\right|^{a, b}$ \\
\hline 2. ONSD (mm), median (IQR) & & $5.36(1)$ & $3.60(1)$ & $4.00(1)$ & $<\left.0.00\right|^{a, b}$ \\
\hline pGCS, median (IQR) & & $12(1)$ & $15(1)$ & $15(1)$ & $<\left.0.00\right|^{a, b, c}$ \\
\hline Mortality, n (\%) & & $53(\mathrm{II})$ & None & None & $<0.001$ \\
\hline
\end{tabular}

IQR: Interquartile range; CT: Computed tomography; ONSD: Optic nerve sheath diameter; mm: Millimeter; pGCS: Pediatric Glasgow Coma Score (a: for traumatic brain injury and, isolated skull fracture $p<0.05$; b: for traumatic brain injury and normal brain $C T p<0.05$; : for an isolated skull fracture and normal brain $C T p<0.05$ ).

Table 2. Relationship between Pediatric Glasgow Coma Score and optic nerve sheath diameter values

\begin{tabular}{llc}
\hline & \multicolumn{2}{l}{ Pediatric Glasgow Coma Score } \\
\cline { 2 - 3 } & \multicolumn{1}{r}{$\mathbf{p}$} & $\mathbf{p}$ \\
\hline I. ONSD $(\mathrm{mm})$ & $-0.528^{*}$ & $<0.001$ \\
2. ONSD $(\mathrm{mm})$ & $-0.476^{*}$ & $<0.00$ I \\
\hline *: Corelation $p<0.001$; ONSD: Optic nerve sheath diameter.
\end{tabular}

that most of the patients are male and that the severity of trauma increases with the advancing age. ${ }^{[16,17]}$ Ong et al. ${ }^{[18]}$ have attributed this to high-risk behaviors that are common in male children. Compatible with the literature, we found that the number of male children with TBI was higher, the age of these patients was higher than others, and the incidence of TBI was higher in boys in the present study. This can be attributed to that boys play more aggressive games and are more prone to violence than girls. It may also be associated with the fact that sutures of young children are not closed or

Table 3. Optic nerve sheath diameter difference between two measurements of groups

\begin{tabular}{|c|c|c|c|c|}
\hline & I. ONSD & 2. ONSD & Difference & $\mathbf{p}$ \\
\hline & Mean $\pm S D$ & Mean \pm SD & Mean \pm SD & \\
\hline Parenchymal damage $(+)$ (Alive) $(n=449)$ & $4.79 \pm 0.83$ & $4.82 \pm 0.81$ & $-0.028 \pm 0.068$ & $<0.001$ \\
\hline Parenchymal damage $(+)$ (Exitus $)(n=46)$ & $4.93 \pm 0.81$ & $5.02 \pm 0.72$ & $-0.08 \pm 0.12$ & $<0.001$ \\
\hline Subarachnoid hemorrhage $(n=222)$ & $4.77 \pm 0.86$ & $4.79 \pm 0.85$ & $-0.018 \pm 0.05$ & $<0.001$ \\
\hline Subdural hemorrhage $(n=|| 2)$ & $4.75 \pm 0.81$ & $4.79 \pm 0.79$ & $-0.04 I \pm 0.07$ & $<0.001$ \\
\hline Epidural hemorrhage $(n=107)$ & $4.98 \pm 0.76$ & $5.02 \pm 0.74$ & $-0.04 \pm 0.08$ & $<0.001$ \\
\hline Cerebral contusion $(n=101)$ & $4.69 \pm 0.84$ & $4.74 \pm 0.82$ & $-0.05 \pm 0.075$ & $<0.001$ \\
\hline Cerebral edema $(n=68)$ & $4.76 \pm 0.80$ & $4.8 I \pm 0.78$ & $-0.048 \pm 0.069$ & $<0.001$ \\
\hline Isolated skull fracture $(n=\mid 43)$ & $3.7 I \pm 0.52$ & $3.75 \pm 0.51$ & $-0.04 \pm 0.08$ & $<0.001$ \\
\hline Normal $(n=155)$ & $3.79 \pm 0.53$ & $3.80 \pm 0.52$ & $-0.02 \pm 0.06$ & $<0.001$ \\
\hline
\end{tabular}

SD: Standard deviation; ONSD: Optic nerve sheath diameter; SD: Standard deviation. 
have been recently closed, or that they have more tolerance to trauma due to the relatively low ossification.

Studies in the literature have reported that the cause of TBI in the pediatric population is fall and the incidence of traffic accidents increases with the advancing age. ${ }^{[16,17,19]}$ In the present study, fall has been the most common cause of injury and the number of TBI and ISF cases developed as a result of a traffic accident has been the lowest. This may be due to children fall as a result of being careless while playing or when they were in a high-rise place. The clinician wants to rule out a possible TBI since other injuries, as well as head injury, are frequently observed in traffic accident cases. This may have caused the frequency of pathology to be low in brain CTs. In traumas caused by falls, the physical examination is clearer and more specific, and the trauma coming directly to the head may have increased the rate of ISF and TBI.

Studies with the pediatric population have reported that skull fracture is the most common lesion and epidural hematoma is the most common complication of TBI. ${ }^{[16,17]}$ Compatible with the literature, skull fracture ranks the first place concerning incidence in the present study. However, unlike the literature, subarachnoid hemorrhage has been the most common complication in TBI. This may be due to the trauma mechanism, severity of the trauma, and admission of patients with poor clinical status to tertiary hospitals like our hospital. Many studies have shown that ONSD measured on brain CT is associated with TBP-related ICP increase and has drawn attention to the high sensitivity and negative predictive value of ONSD. ${ }^{[9,20,21]}$ There are also studies showing a correlation between the ONSD measured using USG or CT and ICP in pediatric patients. ${ }^{[13,22]}$ In a study by Young et al. ${ }^{[23]}$ involving pediatric patients, have reported that there is an increase in ONSD value in cases with TBI and that ONSD can be used in ICP monitoring. In the present study, the ONSD value of patients with TBI in the first and second measurements has been found to be higher than the patients with ISF or normal brain CT findings, compatible with the literature. We believe that this is associated with an increase in ICP caused by increased brain edema due to both primary and secondary injuries.

The pGCS is an important clinical parameter in determining the clinical status of pediatric patients with a head injury. ${ }^{[2,6,24]}$ Therefore, current guidelines recommend the use of pGCS in the follow-up of children with TBI. ${ }^{[25]}$ Young et al. ${ }^{[23]}$ have reported a significant relationship between pGCS and ONSD in their study involving pediatric patients. In a study by Yagar et al. ${ }^{[26]}$ in which the ONSD measurement was performed using cranial CT in patients with a head injury, the ONSD value of children with a PGCS of 3 to 13 has been reported to be higher than those with a PGCS of 14 or 15. In the present study, the pGCSs of the patients with TBI have been found to be significantly lower than those with ISF and normal CT findings. We have further found that PGCS decreases as the ONSD value increases. We believe that this is due to that ONSD increases as a result of deterioration in intracranial circulation because of the increased severity of TBI. As a contrary relationship, the patient's clinical status is impaired and consciousness becomes deepen as the severity of TBI increases. We believe that a negative correlation has been found between pGCS and ONSD due to this contrary relationship.

Specific symptoms of ICP increase may not always be seen in the pediatric patient group, which can lead to an overlook of ICP increase. ${ }^{[I]}$ In TBI cases, secondary injuries, as well as brain damage caused by primary injury, may also cause brain edema and thus an increase in ICP, resulting in impaired clinical status. ${ }^{[6,27,28]}$ In the literature, it has been reported that ONSD is an independent variable for morbidity and mortality, and mortality rates have been lower in patients who underwent ICP monitoring and required interventions. ${ }^{[29,30]}$ To our knowledge, there is no study in which serial ONSD monitoring is performed in pediatric head trauma cases in the literature. However, in a study conducted by Thotakura et al. ${ }^{[31]}$ in which ONSD was measured with an interval of 24-48 hours in adult head trauma cases, it was reported that the clinical course was good in all patients in the group with a decrease in their ONSD values and that none of the patients in this group received surgical treatment.

In the present study, a significant increase has been observed in the ONSD values of the patients (alive, died, with and without CT lesion) who had to undergo control brain CT due to any reason (clinical change, new symptom, or follow-up). We believe that ONSD values of the patients with parenchymal injury have increased due to the ICP, which increases due to the effect of the increase in the amount of bleeding on the mass and secondary injuries that develop over time. Although some patient groups have normal brain CT results or ISF, we believe that ONSD increases by the ICP that increases due to very small amounts of bleeding, axonal injuries, and secondary effects of trauma in these patient groups. It should be considered that the physician may have requested control brain CT since increased ICP in these patient groups may have led to new symptoms and changes in the clinical status. It is noteworthy that the most significant increase has been observed in patients with $\mathrm{TBI}$ and patients with a mortal clinical course. This has led to the emergence of the idea that patients with a significant increase in ONSD values have a more mortal clinical course and that it may guide the physician to change the treatment plan. We believe that this repeated measurement showing an increase in ONSD on a brain CT that has been already taken may guide the clinician in terms of follow-up and treatment.

The greatest limitation of this study is that why the control brain $\mathrm{CT}$ is performed and whether there is a change in the control pGCS are not known due to its retrospective design. There were no comparable results of invasive ONSD measurement known as a gold standard. 


\section{Conclusion}

The results of our study suggest that the evaluation of ICP using brain CT-based ONSD measurements is extremely helpful in predicting the severity of trauma on admission in patients with head trauma patients. Pathologic brain CT findings and PGSCs were compatible with the results of ONSD measurements. Increased ICP levels in repeated ONSD measurements are also meaningful in terms of early diagnosis of adverse outcomes due to secondary insult of traumatic brain injury. Brain CT-based ONSD measurements should be considered as a non-invasive and effective method in monitoring the increase of intracranial pressure in the emergency admissions, follow-up, and treatments of pediatric patients with head trauma.

Ethics Committee Approval: Approved by the local ethics committee.

\section{Peer-review: Internally peer-reviewed.}

Authorship Contributions: Concept: R.P.K., N.K., M.Ö.; Design: R.P.K., N.K., M.Ö.; Supervision: R.P.K.; Materials: R.P.K., N.K., N.E.; Data: R.P.K., N.K., M.Ö., N.E.; Analysis: B.K., N.K.; Literature search: R.P.K., B.K., M.Ö.; Writing: R.P.K., N.K.; Critical revision: R.P.K.

Conflict of Interest: None declared.

Financial Disclosure: The authors declared that this study has received no financial support.

\section{REFERENCES}

1. Lovett ME, O'Brien NF, Leonard JR. Children With Severe Traumatic Brain Injury, Intracranial Pressure, Cerebral Perfusion Pressure, What Does it Mean? A Review of the Literature. Pediatr Neurol 2019;94:320 [CrossRef]

2. Araki T, Yokota H, Morita A. Pediatric Traumatic Brain Injury: Characteristic Features, Diagnosis, and Management. Neurol Med Chir (Tokyo) 2017;57:82-93 [CrossRef]

3. Bardes JM, Benjamin E, Escalante AA, Wu J, Demetriades D. Severe traumatic brain injuries in children: Does the type of trauma center matter?. J Pediatr Surg 2018;53:1523-5. [CrossRef]

4. Dilmen ÖK, Akçıl EF, Tunalı Y. Intensive Care Treatment in Traumatic Brain Injury. Turk J Anaesthesiol Reanim 2015;43:1- . [CrossRef]

5. Hussain E. Traumatic Brain Injury in the Pediatric Intensive Care Unit. Pediatr Ann 2018;47:e274 9. [CrossRef]

6. Vella MA, Crandall ML, Patel MB. Acute Management of Traumatic Brain Injury. Surg Clin North Am 2017;97:1015-34. [CrossRef]

7. Robba C, Bacigaluppi S, Cardim D, Donnelly J, Bertuccio A, Czosnyka M. Non-invasive assessment of intracranial pressure. Acta Neurol Scand 2016;134:4-21 [CrossRef]

8. Narayan V, Mohammed N, Savardekar AR, Patra DP, Notarianni C, Nanda A. Noninvasive Intracranial Pressure Monitoring for Severe Traumatic Brain Injury in Children: A Concise Update on Current Methods. World Neurosurg 2018;114:293-300. [CrossRef]

9. Sekhon MS, Griesdale DE, Robba C, McGlashan N, Needham E, Walland $\mathrm{K}$, et al. Optic nerve sheath diameter on computed tomography is correlated with simultaneously measured intracranial pressure in patients with severe traumatic brain injury Intensive Care Med 2014;40:1267-74.
10. Luerssen TG. Intracranial pressure: current status in monitoring and management. Semin Pediatr Neurol 1997;4:146—55 [CrossRef]

11. Komut E, Kozacı N, Sönmez BM, Yılmaz F, Komut S, Yıldırım ZN, et al. Bedside sonographic measurement of optic nerve sheath diameter as a predictor of intracranial pressure in ED. Am J Emerg Med 2016;34:963-7 [CrossRef]

12. Jenjitranant P, Tunlayadechanont P, Prachanukool T, Kaewlai R. Correlation between optic nerve sheath diameter measured on imaging with acute pathologies found on computed tomography of trauma patients. Eur J Radiol 2020;125:10887 . [CrossRef]

13. Kerscher SR, Schöni D, Hurth H, Neunhoeffer F, Haas-Lude K, Wolff $\mathrm{M}$, et al. The relation of optic nerve sheath diameter (ONSD) and intracranial pressure (ICP) in pediatric neurosurgery practice - Part I: Correlations, age-dependency and cut-off values. Childs Nerv Syst 2020;36:99-106 [CrossRef]

14. Khan MN, Shallwani H, Khan MU, Shamim MS. Noninvasive monitoring intracranial pressure - A review of available modalities. Surg Neurol Int 2017;8:51, [CrossRef]

15. Munawar K, Khan MT, Hussain SW, Qadeer A, Shad ZS, Bano S, et al. Optic Nerve Sheath Diameter Correlation with Elevated Intracranial Pressure Determined via Ultrasound. Cureus 2019;11:e4145. [CrossRef]

16. Ișık HS, Gökyar A, Yıldız Ö, Bostancı U, Özdemir C. Pediatric head injuries, retrospective analysis of 851 patients: an epidemiological study. Turkish J Trauma \& Emerg Surg 2011;17:166-72. [CrossRef]

17. Ökten Aİ, Yalman M, Kaplanoğlu E, Gül B, Gezici AR, Sertel İ, et al. Pediatric head traumas. Turkish J Trauma \& Emerg Surg 1996;2:94-9.

18. Ong AC, Low SG, Vasanwala FF. Childhood Injuries in Singapore: Can Local Physicians and the Healthcare System Do More to Confront This Public Health Concern? Int J Environ Res Public Health 2016;13:718.

19. Langlois J, Rutland-Brown W, Thomas K. Traumatic Brain Injury in the United States: Emergency Department Visits, Hospitalizations, and Deaths 2002-2006. Atlanta, GA: Centers for Disease Control and Prevention; 2006 [CrossRef]

20. Maas AI, Hukkelhoven CW, Marshall LF, Steyerberg EW. Prediction of outcome in traumatic brain injury with computed tomographic characteristics: a comparison between the computed tomographic classification and combinations of computed tomographic predictors. Neurosurgery 2005;57:1173—82. [CrossRef]

21. Legrand A, Jeanjean P, Delanghe F, Peltier J, Lecat B, Dupont H. Estimation of optic nerve sheath diameter on an initial brain computed tomography scan can contribute prognostic information in traumatic brain injury patients. Crit Care 2013;17:R61 [CrossRef]

22. Lin JJ, Chen AE, Lin EE, Hsia SH, Chiang MC, Lin KL. Point-of-care ultrasound of optic nerve sheath diameter to detect intracranial pressure in neurocritically ill children - A narrative review. Biomed J. $2020 \mathrm{Apr}$ 23:S2319-4170(20)30032-9. doi: 10.1016/j.bj.2020.04.006. [Epub ahead of print [CrossRef]

23. Young AM, Guilfoyle MR, Donnelly J, Scoffings D, Fernandes H, Garnett $M$, et al. Correlating optic nerve sheath diameter with opening intracranial pressure in pediatric traumatic brain injury. Pediatr Res 2017;81:443一․ [CrossRef]

24. O'Brien NF, Maa T, Reuter-Rice K. Noninvasive screening for intracranial hypertension in children with acute, severe traumatic brain injury. $\mathrm{J}$ Neurosurg Pediatr 2015;16:420- [CrossRef]

25. Kochanek PM, Tasker RC, Carney N, Totten AM, Adelson PD, Selden NR, et al. Guidelines for the Management of Pediatric Severe Traumatic Brain Injury, Third Edition: Update of the Brain Trauma Foundation Guidelines. Pediatr Crit Care Med 2019;20:S1-82 [CrossRef]

26. Yagar AB, Kozaci N, Avci M, Yildiz S, Karaman Y. Determination of op- 
tic nerve sheath diameter variability with age in pediatric groups and comparison of increased intracranial pressure and optic nerve sheath diameter in pediatric patients with head trauma Ann MedRes 2018;25:460-5.

27. Sönmez BM, Temel E, İşcanlı MD, Yllmaz F, Gülöksüz U, Parlak S, Uçkun ÖM. Is initial optic nerve sheath diameter prognostic of specific head injury in emergency department 5 ? J Natl Med Assoc 2019;111:210-7.

28. Hon KL, Huang S, Poon WS, Cheung HM, Ip P, Zee B. Mortality And Morbidity of Severe Traumatic Brain Injuries; A Pediatric Intensive Care Unit Experience Over 15 Years. Bull Emerg Trauma 2019;7:256-62.

29. Karakitsos D, Soldatos T, Gouliamos A, Armaganidis A, Poularas J,
Kalogeromitros A, et al. Transorbital sonographic monitoring of optic nerve diameter in patients with severe brain injury. Transplant Proc 2006;38:3700- 6 [CrossRef]

30. Al Saiegh F, Philipp L, Mouchtouris N, Chalouhi N, Khanna O, Shah $\mathrm{SO}$, et al. Comparison of Outcomes of Severe Traumatic Brain Injury in 36,929 Patients Treated with or without Intracranial Pressure Monitoring in a Mature Trauma System. World Neurosurg 2020;136:e535-41.

31. Thotakura AK, Marabathina NR, Danaboyina AR, Mareddy RR. Role of serial ultrasonic optic nerve sheath diameter monitoring in head injury. Neurochirurgie 2017;63:444-8 [CrossRef]

\section{ORİJINAL ÇALIŞMA - ÖZET}

\section{Kafa travmalı çocuklarda optik sinir kılıf çapı ölçümlerinin klinik seyir ile uyumu \\ Dr. Rasime Pelin Kavak, ${ }^{1}$ Dr. Meltem Özdemir, ${ }^{1}$ Dr. Nezih Kavak, ${ }^{2}$ Dr. Nurcan Ertan, ${ }^{1}$ Dr. Bahadır Külah ${ }^{3}$}

${ }^{1}$ Sağıık Bilimleri Üniversitesi Dışkapı Yıldırım Beyazıt Eğitim ve Araştırma Hastanesi, Radyoloji Kliniği, Ankara
${ }^{2}$ Sağlık Bilimleri Üniversitesi Dışkapı Yıldırım Beyazıt Eğitim ve Araştırma Hastanesi, Acil Tıp Kliniği, Ankara

${ }^{3}$ A Life Park Uluslararası Akademik Hastanesi, Genel Cerrahi Kliniği, Ankara

AMAÇ: Travmatik beyin hasarlı (TBH) çocuklarda kafa içi basıncının (KiB) takibi prognoz ve tedavi açısından önemlidir. Optik sinir kılıf çapı (OSKÇ) ölçümleri kafa içi basıncının monitorizasyonunda önerilen yöntemlerden birisidir. Bu çalışmada, TBH olan pediatrik olguların takibinde beyin bilgisayarlı tomografideki (BT) OSKÇ değişiminin pediatrik Glasgow Koma Skoru (PGKS) ile korelasyonunu değerlendirmeyi ve aynı zamanda KiB göstergesi olan OSKÇ’nin hasta takibinde kullanılabilirliğini değerlendirmeyi amaçladık.

GEREÇ VE YÖNTEM: Ocak 2016-Ocak 2018 tarihleri arasında acil servise kafa travması ile başvuran 92I pediatrik hasta geriye dönük olarak değerlendirildi. Yaş, cinsiyet, travma tipi, beyin BT bulguları, pGKS, serebral hemoraji tipleri ve izole kafatası kırıkları (IKK) incelendi. Hastalar BT bulgularına dayalı; parankimal beyin hasarı, IKK ve normal beyin BT'si olanlar şeklinde üç grupta değerlendirildi. OSKÇ ölçümü BT ile yapıldı. Hastaların OSKÇ ölçüm sonuçlarının klinik verilerle uyumu karşılaştıııldı.

BULGULAR: Çalışmamızda hastaların yaş ortancası $36(\mathrm{IQR}=64)$ ay olup, hastaların \%64.2'si erkekti. Parankimal yaralanması hastaların OSKÇ'si ve pGKS'si, İKK olan ve normal beyin BT'si olan hastalardan anlamlı olarak yüksek saptandı $(p<0.05)$. Çalışmamızda pGKS'nin birinci ve ikinci ölçüm OSKÇ değerleri arasında negatif yönlü anlamlı korelasyon verdiği saptandı $(p<0.05)$. Çalışmamıza almış olduğumuz ve kontrol beyin BT'si çekilen gruplarda, ikinci beyin BT'de saptanan OSKÇ düzeyleri anlamlı olarak yüksek saptandı $(p<0.05)$.

TARTIŞMA: Beyin BT bulguları ve pGKS birlikte değerlendirildiğinde OSKÇ ölçümleri klinik takipte güvenilir ve anlamlı parametrelerdir. Tekrarlayan OSKÇ ölçümlerinin, ikincil yaralanmaların olası olumsuz etkilerini ve başvuru esnasında yaşanan travmanın şiddetini belirlemede faydalı olacağına inanıyoruz.

Anahtar sözcükler: Kafa içi basınç; optik sinir kılıf çapı; travmatik beyin hasarı.

Ulus Travma Acil Cerrahi Derg 2020;26(5):728-734 doi: 10.14744/tjtes.2020.13446 